\title{
XXVI. High resistances used in connexion with the D'Arsonval galvanometer
}

\section{Frederick J. Smith}

To cite this article: Frederick J. Smith (1893) XXVI. High resistances used in connexion with the D'Arsonval galvanometer, Philosophical Magazine Series 5, 35:214, 210-211, DOI: 10.1080/14786449308620406

To link to this article: http://dx.doi.org/10.1080/14786449308620406

曲 Published online: 08 May 2009.

Submit your article to this journal $\sqsubset \pi$

Џ Article views: 3

Q View related articles $\asymp$ 
the line D. But Protessor Dewar has kindly furnished me with a more recent determination of what he believes to be a purer specimen. The refractive index, at the boiling-point, for the line $\mathrm{C}$ is 1.3445 , and for the line $\mathrm{F}$ is 1.3528 , the specific gravity being 0.55 . These tigures give 17.53 as the molecular refraction for the line $\mathrm{C}$, and 17.92 for the line $\mathrm{F}$. These will indicate about $17 \cdot 41$ for the line $A$. The theo. retical value for ethylene, for the line $A$, is $17 \cdot 4$.

$$
\begin{aligned}
& \mathrm{C}_{2} \text {. . . }=10 \cdot 0 \\
& \mathrm{H}_{4} \text {. . . }=5 \cdot 2 \\
& \text { Double-linking . . . }=2 \cdot 2 \\
& 17 \cdot 4
\end{aligned}
$$

The coincidence between experiment and theory is very striking.

XXVI. High Resistances used in connexion with the $D^{\prime} A r-$ sonval Galvanometer. By Frederiok J. Sмтtн, Millard Lecturer in Mechanics, Trinity College, Oxjord*.

TWHE great utility of the D'Arsonval galvanometer for 1 determining current by the fall of potential method must have been felt by all who have used it for this purpose. When the instrument is thus applied, a large resistance is required in the galvanometer circuit. This is usually made of wire, and costs much. In 1890 I read a short paper before the Ashmolean Society of Oxford on the subject of resistances made of non-metallic substances and mercury jet-contacts.

Since then resistances of this kind have been constantly in use in the Millard Laboratory, and they have proved themselves to be both reliable and constant. They are made thus: Dry plaster of Paris and electrotype plumbago are intimately mixed together in suitable proportions $f$, the composition is then rammed tightly into a glass tube furnished with a platinum terminal; when nearly full another terminal is introduced and fixed in the substance by compression; the end of the tube is then closed over the wire in the blowpipe flame, and the resistance is finished.

In one resistance thus made the glass tube is 10 centim. long and 0.4 centim. in internal diameter, and has a resistance of about one megohm. Very finely powdered glass mixed with plumbago makes a good composition for high

* Comsunicated by the Author.

+ Equal quantities of each in a tube 0.4 centim. diameter and 11.5 centim. long gave a resistance of 65,000 ohms. 
resistances, but it is not so easily manipulated as the p!aster and plumbago. Out of a large number of different substances tried, I find these two the most reliable. A megohm made by the method I have described costs only a few shillings.

Since October 1888 a D'Arsonval galvanometer has been in constant use here, in combination with a photographic apparutus, whereby a cylinder carrying bromide paper is constantly exposed to the reflected light from the galvanometer which shines through a long narrow slit placed in front of the revolving cylinder; by this means a constant record is kept of the current in a certain circuit. When the resistance of the galvanometer circuit is very high, the dead-beat action of the instrument is somewhat affected. I find that if a fow turns of fine covered copper wire are wound on the outside of the rectangular coil of the instrument so as to form a closed circuit, it gives the same reading as before for a given potential difference, and is perfectly dead-beat in its action, so that with the addition of this damping-coil any amount of resistance may be used in the circuit of the galvanometer.

Trinity College, Oxford,

Feb. 10, 1893 .

\section{The Laws of Molecular Force.}

By William Sutherland, M.A., B.Sc.*

TN my last paper on this subject (Phil. Mag. April 1889) it was shown that if the law of force between two similar molecules is $3 \mathrm{Am}^{2} / r^{4}$, the parameter A could be calculated for a large number of bodies from Robert Schiff's measurements of their surface-tensions, and a law was announced connecting the values of $A$ with chemical composition ; but as this law was affected with exceptions in the case of the organic bromides and iodides and the amines, and as the argument from surface-tension requires the introduction of a considerable number of assumptions, I felt that it was very desirable to secure some other means of finding $A$. It soon appeared that the only satisfactory plan would be to return again to the search for the true characteristic equation of fluids on the model of Clausins's virial equation, as I had found that not one of those hitherto advanced was capable of general application. Fortunately the experimental material now available is so abundant and so well placed that $I$ was completely successful in the quest, in the more tedious parts of which I had the advantage of assistance from my brother,

* Communicated by the Physical Society: read Oct. 28, 1892. 